\title{
TOMASZ DŁUGOSZ
}

ORCID: 0000-0003-3174-1568

Uniwersytet Jagielloński

dlugosz@dlugosz.com.pl

\section{Wspieranie przez państwo sukcesji międzypokoleniowej w gospodarce na gruncie ustawy o zarządzie sukcesyjnym przedsiębiorstwem osoby fizycznej}

\begin{abstract}
Abstrakt: Ustawa o zarządzie sukcesyjnym przedsiębiorstwem osoby fizycznej zawiera regulacje typu publicznoprawnego, które wspierają sukcesję międzypokoleniową w gospodarce, służąc $\mathrm{w}$ ten sposób realizacji celów strukturalnych. Można wyróżnić kilka elementów tak rozumianego wsparcia gospodarki.
\end{abstract}

Słowa kluczowe: zarząd sukcesyjny, przedsiębiorstwo w spadku, zmiany strukturalne w gospodarce, sukcesja administracyjnoprawna.

\section{Wprowadzenie}

W listopadzie 2018 roku weszła w życie ustawa z dnia 5 lipca 2018 roku o zarządzie sukcesyjnym przedsiębiorstwem osoby fizycznej ${ }^{1}$ (dalej: u.z.s.). Zapowiedź tej ustawy pojawiła się już w czerwcu 2016 roku, gdy Ministerstwo Rozwoju ogłosiło dokument pod tytułem „Pakiet 100 zmian dla firm”. Konstytucja biznesu, pakiet 100 zmian dla firm oraz rozwiązania rozszerzające zachęty inwestycyjne miały tworzyć — jak ogłosił premier — system wspierania przedsię-

1 Dz.U. z 2018 r. poz. 1629. 
biorczości w Polsce, którego wprowadzenie stanowi „największą reformę prawa gospodarczego po 1989 roku"2.

Czytając ustawę o zarządzie sukcesyjnym, można odnieść wrażenie, że dotyczy ona możliwości tymczasowego powołania zarządcy sukcesyjnego na potrzeby zabezpieczenia interesów następców prawnych zmarłego na czas postępowania spadkowego i ewentualnego działu spadku, a więc że w gruncie rzeczy mamy do czynienia z regulacją prywatnoprawną. Głębszy ogląd sprawy prowadzi do wniosku, że ustawa realizuje dalej idące cele, że jest odpowiedzią na poważne wyzwania w dziedzinie gospodarki, jakie wiążą się z prowadzeniem działalności gospodarczej w obecnych warunkach ustrojowych. $Z$ uzasadnienia projektu ustawy wynika, że celem regulacji jest zapewnienie przedsiębiorcom będącym osobami fizycznymi warunków do zachowania ciągłości funkcjonowania przedsiębiorstwa po ich śmierci, przy uwzględnieniu, że przedsiębiorstwo jest dobrem prawnym, mającym nie tylko wartość majątkową i gospodarczą, lecz także społeczną ${ }^{3}$. Wyjaśniono, że jednym z podstawowych wyzwań stojących przed firmami rodzinnymi jest sukcesja pokoleniowa i że dotychczas w wielu wypadkach konieczna była likwidacja przedsiębiorstwa w momencie śmierci przedsiębiorcy, w następstwie czego pojawiały się zagrożenia dla majątku przedsiębiorstwa, zatrudnionych pracowników i obrotu gospodarczego, w tym wierzycieli ${ }^{4}$. Dodatkowym celem regulacji ma być więc wzmocnienie ochrony praw osób trzecich, związanych z prowadzeniem przedsiębiorstwa, w tym pracowników, kontrahentów, konsumentów i innych podmiotów współpracujących z przedsiębiorcą ${ }^{5}$. W dalszej części uzasadnienia projektu ustawy mówi się z kolei o „stworzeniu zachęty do przejmowania i prowadzenia tych przedsiębiorstw" dla spadkobierców ${ }^{6}$. Wynika z tego, że przedmiotową ustawę można postrzegać w kategoriach ogólnego wspierania gospodarki przez państwo, gdy oddziałuje się na gospodarkę przez poprawę prawnej i faktycznej pozycji podmiotów gospodarczych, aby realizować cele strukturalne, gospodarcze lub socjalne ${ }^{7}$. Cele strukturalne mogą polegać na zapewnieniu możliwości długookresowego wzrostu przedsiębiorstw w warunkach traktowania ich jako dobra mającego — jak powiedziano — wartość społeczną.

${ }^{2}$ Minister Przedsiębiorczości i Technologii, Prawo do przedsiębiorczości. Małe firmy, wielkie zmiany, s. 3, http://prawodoprzedsiebiorczosci.parp.gov.pl/wp-content/uploads/2018/04/PARP-broszura-cala.pdf (dostęp: 23.09.2019).

${ }^{3}$ Uzasadnienie rządowego projektu ustawy o zarządzie sukcesyjnym przedsiębiorstwem osoby fizycznej z dnia 22 lutego 2018 roku (druk nr 2293 Sejmu RP VII kadencji), s. 8, http://www.sejm.gov. pl/Sejm8.nsf/druk.xsp?nr=2293 (dostęp: 23.09.2019).

4 Ibidem, s. 4.

5 Ibidem, s. 8.

${ }^{6}$ Ibidem, s. 114

7 Szerzej na temat funkcji państwa polegającej na wspieraniu gospodarki zob. K. Horubski, Wspieranie gospodarki, [w:] System Prawa Administracyjnego, t. 8a. Publiczne prawo gospodarcze, red. R. Hauser, Z. Niewiadomski, A. Wróbel, Warszawa 2018, s. 790 n. 
Zgodnie z obowiązującym brzmieniem art. 1 u.z.s. w omawianej ustawie reguluje: zasady tymczasowego zarządzania przedsiębiorstwem po śmierci przedsiębiorcy, który we własnym imieniu wykonywał działalność gospodarczą na podstawie wpisu do Centralnej Ewidencji i Informacji o Działalności Gospodarczej (dalej: CEIDG) oraz kontynuowania działalności gospodarczej wykonywanej z wykorzystaniem tego przedsiębiorstwa. Wyrażono zatem wprost zasadę kontynuowania działalności gospodarczej z wykorzystaniem przedsiębiorstwa zmarłego przedsiębiorcy.

Pojawia się jednak pytanie, na czym owo kontynuowanie polega i czy stoją za nim środki wsparcia gospodarki, a jeżeli tak, to jakie, gdyż może być również tak, że art. 1 u.z.s. wyraża jedynie cel, który jest realizowany w ten sposób, że daje się następcom prawnym zmarłego możliwość korzystania z tymczasowego zarządu sukcesyjnego. Jak ogólnie wiadomo, taki cel (ratio legis) miałby wpływ na sposób stosowania przepisów ustawy ${ }^{8}$. W ustawie reguluje się przede wszystkim zarząd sukcesyjny, a jest to funkcja tymczasowa, dlatego też można zgodzić się, że ustawa nie wprowadza trwałego sposobu prowadzenia przedsiębiorstwa ${ }^{9}$, lecz jednocześnie można dostrzec rozwiązania, które służą trwałemu zabezpieczeniu funkcjonowania przedsiębiorstwa pozostawionego przez zmarłego ${ }^{10}$. Wrażenie, że chodzi nie tylko o tymczasowy zarząd majątkiem czy ochronę majątku pozostawionego przez zmarłego przedsiębiorcę wzmaga się, jeśli dostrzeże się nowelizację ustawy z dnia 31 lipca 2019 roku ${ }^{11}$, którą między innymi reguluje się sukcesję administracyjną w odniesieniu do nabywcy przedsiębiorstwa bezpośrednio od: osoby fizycznej, osoby fizycznej i jego małżonka, wspólników spółki cywilnej (zob. dodany art. 45b u.z.s.).

W tym kontekście można zauważyć, iż pogląd, że należy sprzyjać czy umożliwiać kontynuowanie funkcjonowania przedsiębiorstw, jest obecny w wymiarze szerszym — nie tylko w ustawie o zarządzie sukcesyjnym przedsiębiorstwem osoby fizycznej. W szczególności w wielu aktach politycznych Unii Europejskiej dostrzeżono znaczenie „przenoszenia własności przedsiębiorstw”, co wiąże się z tym, że ludność Europy starzeje się i wielu Europejczyków stoi przed alternatywą likwidacji swojego przedsiębiorstwa bądź jego przekazania komuś innemu. Podano szacunkowo w jedynym z dokumentów, że w skali Europy problem ten dotyka każdego roku niemal 690 tysięcy małych i średnich przedsiębiorstw

8 Zob. np. L. Morawski, Zasady wyktadni prawa, Toruń 2006, s. 140.

9 Tak R. Blicharz, Zarząd sukcesyjny przedsiębiorstwem w spadku, Warszawa 2019, wprowadzenie.

${ }^{10}$ Zdaje się to w pewien sposób dostrzegać również K. Kopaczyńska-Pieczniak, której zdaniem podstawą wyodrębnienia przedsiębiorstwa w spadku jest przede wszystkim cel, który polega między innymi na zapewnieniu kontynuowania dotychczasowej działalności profesjonalnej przedsiębiorcy jednoosobowego z wykorzystaniem przedsiębiorstwa w spadku, będącego podstawą wykonywania zarobkowej, zorganizowanej i trw ałej działalności; zob. eadem, Status prawny zarządcy sukcesyjnego, „Przegląd Prawa Handlowego” 2018, nr 12, s. 6.

11 Ustawa z dnia 31 lipca 2019 roku o zmianie niektórych ustaw w celu ograniczenia obciążeń regulacyjnych (Dz.U. poz. 1495). 
i wpływa na 2,8 miliona miejsc pracy ${ }^{12}$. Już w lipcu 1994 roku pojawił się komunikat Komisji Europejskiej na temat wsparcia małych i średnich przedsiębiorstw, w którym zajęto się czterema istotnymi kwestiami w związku z przenoszeniem własności przedsiębiorstw: 1. zapewnieniem ciągłości spółek osobowych i firm jednoosobowych; 2. przygotowaniem do przeniesienia własności przez przyjęcie najodpowiedniejszej formy prawnej; 3. popieraniem przenoszenia własności na strony trzecie oraz 4. udzielaniem pomocy w wypadkach przeniesienia własności $\mathrm{w}$ rodzinie przez odpowiednie ulgi podatkowe ${ }^{13}$. W grudniu 1994 roku opublikowano zalecenie Komisji w sprawie przenoszenia własności małych i średnich przedsiębiorstw, w którym zwrócono się do państw członkowskich między innymi o ustanowienie przepisów prawnych zapewniających ciągłość spółek osobowych i firm jednoosobowych w przypadku śmierci jednego ze wspólników lub właściciela ${ }^{14}$. W 2012 roku, po doświadczeniu skutków kryzysu gospodarczego zapoczątkowanego w 2008 roku, wydano natomiast komunikat Komisji o ,pobudzaniu ducha przedsiębiorczości w Europie" 15 , w którym postulowano również ułatwienia w przenoszeniu własności przedsiębiorstw.

Można dojść do wniosku, że w ustawie o zarządzie sukcesyjnym są regulacje typu publicznoprawnego, które ułatwiają prowadzenie działalności gospodarczej w nawiązaniu do działalności gospodarczej zmarłego przedsiębiorcy czy też poprzednika, opierając się na pozostawionym przez niego lub przekazanym majątku, które chronią też obrót gospodarczy oraz interes publiczny, jak również można dostrzec zachętę do kontynuowali działalności gospodarczej poprzednika z wykorzystaniem pozostawionego czy przekazanego przedsiębiorstwa. Związane z tym wsparcie gospodarki polega na tym, że umożliwia się przeniesienie „działających przedsiębiorstw”, to jest wraz ze związanymi umowami i decyzjami, dając tym samym możliwość wzrostu przedsiębiorstwom w dłuższym okresie, wychodząc poza perspektywę życia jednego człowieka. Omawiana ustawa nie służy więc tylko majątkowej sukcesji międzypokoleniowej, lecz ogólniejszej sukcesji międzypokoleniowej w gospodarce, a do takich podstawowych elementów tego rodzaju wsparcia można zaliczyć:

1. usytuowanie zarządcy sukcesyjnego, które powoduje, że jego zadaniem nie jest tylko troska o majątek zmarłego, ale zapewnienie funkcjonowania przed-

12 Komunikat Komisji do Rady, Parlamentu Europejskiego, Europejskiego Komitetu Ekonomiczno-Społecznego i Komitetu Regionów, Realizacja wspólnotowego programu lizbońskiego na rzecz wzrostu gospodarczego i zatrudnienia. Przenoszenie własności przedsiębiorstw. Ciągłość poprzez nowy początek (COM/2006/0117 final), Wstęp.

13 Komunikat Komisji w sprawie przenoszenia własności przedsiębiorstw, Działania na rzecz MŚP (Dz.U. C 204 z 23.07.1994 r.), s. 1-23.

14 Zalecenie Komisji w sprawie przenoszenia własności małych i średnich przedsiębiorstw (Dz.U. L 385 z 31.12.1994 r.), s. 14-17.

15 Komunikat Komisji do Parlamentu Europejskiego, Rady, EKES I KR, Plan działania na rzecz przedsiębiorczości do 2020 r. Pobudzanie ducha przedsiębiorczości w Europie (COM/2012/0795 final). 
siębiorstwa po śmierci przedsiębiorcy, z uwzględnieniem interesów nie tylko następców prawnych zmarłego;

2. mechanizm kontynuacji uprawnień wynikających z decyzji administracyjnych związanych z przedsiębiorstwem, które uzyskał zmarły, oraz uprawnień wynikających z wpisu do właściwych rejestrów administracyjnych, w tym rejestru działalności regulowanej;

3. reguły działu spadku, gdy w jego skład wchodzi przedsiębiorstwo, przy czym w tym zakresie można dostrzec pewną niekonsekwencję ustawodawcy z punktu widzenia zasady kontynuacji działalności gospodarczej z wykorzystaniem przedsiębiorstwa zmarłego;

4. wprowadzony nowelizacją z dnia 31 lipca 2019 roku mechanizm kontynuacji uprawnień wynikających z decyzji administracyjnych związanych z przedsiębiorstwem w wypadku zbycia przedsiębiorstwa.

\section{Zarządca sukcesyjny}

Jeśli chodzi o zarządcę sukcesyjnego, trzeba zauważyć, że zarząd sukcesyjny jest funkcją tymczasową, na czas potrzeby następcom prawnym zmarłego przedsiębiorcy do przeprowadzenia spraw spadkowych. Zarząd sukcesyjny może być ustanowiony dwojako. Po pierwsze, z chwilą śmierci przedsiębiorcy, gdy sam przedsiębiorca powoła zarządcę sukcesyjnego na wypadek swojej śmierci (zob. art. 9, 10 u.z.s.); po drugie, po śmierci przedsiębiorcy, gdy zarządcy sukcesyjnego nie powołał zmarły, ale powołują go wskazane w ustawie osoby (zob. art. 12 u.z.s.).

Powołanie zarządcy sukcesyjnego po śmierci przedsiębiorcy może nastąpić w stosunkowo krótkim czasie, to znaczy uprawnienie to wygasa z upływem dwóch miesięcy od dnia śmierci przedsiębiorcy (art. 12 ust. 10 u.z.s.). Od chwili ustanowienia zarządu sukcesyjnego zarządca sukcesyjny wykonuje prawa i obowiązki zmarłego przedsiębiorcy wynikające z wykonywanej przez niego działalności gospodarczej oraz prawa i obowiązki wynikające z prowadzenia przedsiębiorstwa w spadku (zob. art. 29 u.z.s.). To prowadzenie przedsiębiorstwa w spadku rozumie się $\mathrm{w}$ doktrynie funkcjonalnie jako prowadzenie działalności gospodarczej z wykorzystaniem przedsiębiorstwa w spadku ${ }^{16}$. Zwraca uwagę, że zarządca sukcesyjny ma obowiązek prowadzenia przedsiębiorstwa w spadku (art. 18 u.z.s. ${ }^{17}$. Samo przedsiębiorstwo w spadku obejmuje mienie przedsiębiorcy w chwili jego śmierci, lecz takie, które — jak się wydaje — zostało przeznaczone przez tego zmarłego do wykonywania działalności gospodarczej. Jest to część masy spadkowej pozostawionej przez zmarłego, którą wyodrębnia się ze względu na funkcję, przy czym nie

16 Tak przynajmniej K. Kopaczyńska-Pieczniak, op. cit., s. 6.

17 Tak też J. Bieluk, Ustawa o zarzadzie sukcesyjnym przedsiębiorstwem osoby fizycznej. Komentarz, Warszawa 2019, s. 70, nb 4. 
ma znaczenia - jak się z reguły przyjmuje — czy można wyodrębnić w związku z tym mieniem przedsiębiorstwo w rozumieniu art. $55^{1}$ k.c., czy też daje się wyodrębnić kilka takich przedsiębiorstw w rozumieniu kodeksu cywilnego ${ }^{18}$.

Zwraca jednak uwagę, że zarządca sukcesyjny nie koncentruje się na tym mieniu, gdyż ma wykonywać prawa i obowiązki zmarłego przedsiębiorcy wynikające ze świadczonej przez niego działalności gospodarczej oraz prowadzić przedsiębiorstwo w spadku. W ten sposób zarządca sukcesyjny ma kontynuować działalność zmarłego i dla tych potrzeb obowiązują rozwiązania szczególne, na przykład nie wygasają stosunki pracownicze łączące zmarłego przedsiębiorcę z pracownikami, ale pomimo śmierci trwają dalej (art. $63^{2} \S 3$ pkt 2 k.p. ${ }^{19}$ ), oraz obowiązują przepisy dotyczące sukcesji publicznoprawnej zawarte w rozdziale 7 u.z.s. Wspomniany rozdział 7 u.z.s. dotyczy tak zwanych decyzji związanych z przedsiębiorstwem, na które składają się różne pozwolenia administracyjne wydane zmarłemu w związku z jego działalnością gospodarczą. Zarządca sukcesyjny ma obowiązek wykonać obowiązki związane z tymi decyzjami (art. 40 ust. 1 u.z.s.); ma też - jak się wydaje - obowiązek wystąpić o potwierdzenie możliwości wykonywania tych decyzji na podstawie art. 38 ust. 1 u.z.s. do właściwych organów, które sprawdzają, czy dana działalność przez zarządcę sukcesyjnego może być wykonywana.

Organ administracji publicznej, który wydał decyzję związaną z przedsiębiorstwem, odmawia, w drodze decyzji, potwierdzenia możliwości jej wykonywania przez zarządcę sukcesyjnego, między innymi gdy nie zostały spełnione warunki do uzyskania danej decyzji związanej z przedsiębiorstwem wynikające z odrębnych przepisów (art. 39 ust. $1 \mathrm{w}$ zw. $\mathrm{z}$ art. 38 ust. 2 pkt 1 u.z.s.), a więc chroniony jest interes publiczny. Podobnie jest w wypadku działalności regulowanej oraz działalności wymagającej wpisu do rejestru innego niż działalności regulowanej (art. 45 ust. 1 i 6 u.z.s.).

Można dodać, że zarządca sukcesyjny działa w imieniu własnym, ale na rachunek właściciela przedsiębiorstwa w spadku, w wymiarze zaś publicznoprawnym bierze na siebie odpowiedzialność, gdyż w przypadku ubiegania się o potwierdzenie możliwości wykonywania decyzji związanej z przedsiębiorstwem ma oświadczyć, że przyjmuje wszystkie warunki zawarte w tej decyzji i zobowiązuje się do wykonania związanych z nią obowiązków (art. 38 ust. 2 pkt 3 u.z.s.).

Nawiasem mówiąc, kwestie związane z odpowiedzialnością zarządcy sukcesyjnego należą do najtrudniejszych, a w sferze publicznoprawnej są wyjątkowo skomplikowane - na przykład w obszarze danin publicznych to przedsiębior-

18 Tak też Ministerstwo Przedsiębiorczości i Technologii, Sukcesja firm jednoosobowych. Ustawa o zarządzie sukcesyjnym przedsiębiorstwem osoby fizycznej. Praktyczny poradnik, listopad 2018, s. 12, http://firmyrodzinne.pl/wp-content/uploads/2019/01/Sukcesja_firm_jednoosobowych-poradnik-MPiT.pdf (dostęp: 26.09.2019).

19 Ustawa z dnia 26 czerwca 1974 roku Kodeks pracy (tekst jedn. Dz.U. z 2019 r. poz. 1040 z późn. zm.). 
stwo w spadku jest w okresie zarządu sukcesyjnego podatnikiem (rozdział 9 u.z.s.) i przedsiębiorstwo w spadku, gdy ustanowiono zarząd sukcesyjny, wstępuje w przewidziane w przepisach prawa podatkowego majątkowe prawa i obowiązki spadkodawcy związane z prowadzoną działalnością gospodarczą (art. $97 \S$ 1a ustawy Ordynacja podatkowa ${ }^{20}$ ).

Ogólnie można stwierdzić, że zarządca sukcesyjny ma środki oraz obowiązek kontynuowania działalności gospodarczej zmarłego przy wykorzystaniu przedsiębiorstwa w spadku i czyni to z myślą nie tylko o właścicielach przedsiębiorstwa w spadku, skoro ma wykonywać prawa i obowiązki zmarłego przedsiębiorcy wynikające z wykonywanej przez niego działalności gospodarczej oraz z prowadzenia przedsiębiorstwa w spadku, w tym realizować umowy zawarte przez zmarłego i poddawać kontroli wykonywanie decyzji związanych z przedsiębiorstwem, jego działalność zaś jest pod kontrolą społeczną, ponieważ każdy, kto ma interes prawny, może wnosić do sądu o odwołanie zarządcy sukcesyjnego z powodu rażącego naruszenia jego obowiązków (art. $665^{2} \S 1$ k.p.c. ${ }^{21}$ ). Można dodać, że ta kontynuacja odbywa się na warunkach szczególnych, między innymi odpowiedniego stosowania przepisów o wykonywaniu działalności gospodarczej przez przedsiębiorcę (art. 5 u.z.s.) oraz podziału kompetencji, gdyż w wypadku czynności przekraczających zakres zwykłego zarządu zarządca sukcesyjny musi ubiegać się o zgodę wszystkich właścicieli przedsiębiorstwa w spadku lub sądu (art. 22 ust. 1 u.z.s.). W takich warunkach siłą rzeczy działanie zarządcy sukcesyjnego będzie zachowawcze, ukierunkowane na ochronę mienia, zachowanie funkcjonalności przedsiębiorstwa i wykonywanie obowiązków związanych z przedsiębiorstwem w spadku.

\section{Kontynuacja uprawnień wynikających z decyzji i wpisów do właściwych rejestrów}

Jeśli chodzi o mechanizm kontynuacji uprawnień wynikających z decyzji związanych z przedsiębiorstwem, które uzyskał zmarły, oraz wynikających z wpisu zmarłego do właściwych rejestrów, w tym rejestru działalności regulowanej, to - jak powiedziano - zarządca sukcesyjny powinien wystąpić z wnioskami do administracji publicznej służącymi czasowemu utrzymaniu w mocy zezwoleń uzyskanych przez zmarłego oraz skutków wpisów zmarłego do właściwych rejestrów, w tym rejestru działalności regulowanej (rozdział 7 u.z.s.). W ten spo-

${ }^{20}$ Ustawa z dnia 29 sierpnia 1997 roku — Ordynacja podatkowa (tekst jedn. Dz.U. z 2019 r. poz. 900 z późn. zm.).

21 Ustawa z dnia 17 listopada 1964 roku Kodeks postępowania cywilnego (tekst jedn. Dz.U. z 2019 r. poz. 1460 z późn. zm.). 
sób daje się następcom prawym zmarłego czas, aby załatwili sprawy spadkowe, a jednocześnie działalność gospodarcza zmarłego może być kontynuowana przez zarządcę sukcesyjnego nawet wtedy, gdy jest reglamentowana. W tym kontekście R. Blicharz mówi o „okresie prolongacyjnym”22.

Decyzja związana z przedsiębiorstwem wygasa dopiero z upływem sześciu miesięcy od dnia wygaśnięcia zarządu sukcesyjnego, chyba że przed upływem tego terminu następcy prawni zmarłego (właściciele przedsiębiorstwa w spadku) wystąpią o przeniesienie na nich decyzji związanych z przedsiębiorstwem (art. 43 ust. 1 u.z.s.). Podobnie jest w wypadku działalności regulowanej zmarłego oraz działalności wymagającej wpisu do innego niż rejestr działalności regulowanej rejestru prowadzonego przez organ administracji publicznej, w przypadku których zarządca składa wnioski do rejestrów o zmianę danych i dopiero po ustaniu pełnienia funkcji przez zarządcę sukcesyjnego wpisy te się wykreśla (art. 45 ust. 7 i 8 u.z.s.).

Przedstawione regulacje odnoszą się do zarządcy sukcesyjnego, lecz trzeba zauważyć, że nie ma przymusu ustanowienia zarządu sukcesyjnego i że następcy prawni zmarłego (właściciele przedsiębiorstwa w spadku) mogą złożyć do właściwych organów administracyjnych wnioski o przeniesienie na nich decyzji w terminie sześciu miesięcy od dnia wygaśnięcia zarządu sukcesyjnego albo w terminie sześciu miesięcy od dnia śmierci przedsiębiorcy, jeżeli nie został ustanowiony zarząd sukcesyjny (zob. art. 37 ust. $1 \mathrm{w}$ zw. z art. 42 ust. 1 u.z.s.). Takie wnioski o przeniesienie decyzji związanych z przedsiębiorstwem zdają się rozpatrywane na ogólnym zasadach, trudno w tej kwestii dostrzec jakieś szczególne traktowanie z racji odesłania do warunków uzyskania decyzji określonych w odrębnych przepisach (zob. art. 42 ust. 2 pkt 1 u.z.s.). Inaczej zdaje się to postrzegać R. Blicharz ${ }^{23}$. Ważne jest jednak, że — po pierwsze - ogólnie przedłuża się obowiązywanie decyzji związanych z przedsiębiorstwem, które uzyskał zmarły na podstawie art. 37 ust. 1 u.z.s., czyli że w ogóle ma miejsce tak zwana prolongata, dając tym samym możliwość prowadzenia działalności gospodarczej po śmierci przedsiębiorcy, a — po wtóre — że daje się możliwość „przeniesienia decyzji”, a więc utrzymania dotychczasowej decyzji z zachowaniem ciągłości w stosunku do działalności poprzednika, co na gruncie odrębnych ustaw z zakresu reglamentacji może mieć istotne znaczenie. Można dodać, że w omawianej ustawie nie ma przepisów, które odnosiły się na tej samej zasadzie do utrzymania wpisów działalności regulowanej czy wpisów do innych rejestrów w warunkach nieustanowienia zarządu sukcesyjnego - tę kwestię ewentualnie mogą regulować odrębne ustawy.

22 R. Blicharz, op. cit., s. 77.

23 Ibidem, s. 85. 


\section{Dział spadku z przedsiębiorstwem}

Jeśli chodzi o dział spadku, gdy w jego skład wchodzi przedsiębiorstwo, to uwagę zwracają dwie regulacje, które wprowadzono ustawą. Przede wszystkim dopuszczono, aby częściowy dział spadku w sądzie nastąpił z tego powodu, że w skład spadku wchodzi przedsiębiorstwo (art. 1038 § 3 k.c. ${ }^{24}$ ). Może zastanawiać, co właściwie oznacza ta regulacja, ale wydaje się, że chodzi tu o konieczność każdoczesnego rozważenia przez sąd, czy społeczno-gospodarcze przeznaczenie przedsiębiorstwa w spadku nie sprzeciwia się przejściowo dokonaniu zniesienia współwłasności z takim skutkiem, że sąd może nawet — jak się wydaje — oddalić jako przedwczesny wniosek o podział tego przedsiębiorstwa ${ }^{25}$. Natomiast niekonsekwencję można dostrzec w tym, że w kolejnym art. $1038^{1}$ k.c. uzależnia się uwzględnienie w postępowaniu działowym potrzeb zapewnienia kontynuacji działalności gospodarczej z wykorzystaniem przedsiębiorstwa w spadku od porozumienia co do kontynuacji działalności spadkobierców oraz małżonka spadkodawcy, któremu przysługuje udział w przedsiębiorstwie. Znaczy to, że z jednej strony w postępowaniu działowym uwypukla się zasadę kontynuowania działalności gospodarczej wykonywanej z wykorzystaniem przedsiębiorstwa w spadku, lecz z drugiej — uzależnia takową kontynuację od zgody następców prawnych zmarłego. Jest to inne rozwiązanie niż w wypadku sądowego zniesienia współwłasności gospodarstwa rolnego, w przypadku którego sąd uwzględnia społeczno-gospodarcze przeznaczenie gospodarstwa rolnego nawet przy niewyrażeniu zgody przez wszystkich współwłaścicieli (zob. art. $214 \S 1$ k.c.). Wyłania się zatem pytanie, jakie konsekwencje ma niewyrażenie zgody przez następców prawnych zmarłego na kontynuowanie działalności gospodarczej z wykorzystaniem przedsiębiorstwa w spadku i czy wtedy zasada kontynuowania działalności gospodarczej wykonywanej z wykorzystaniem przedsiębiorstwa w spadku przestaje obowiązywać bezwzględnie.

\section{Sukcesja w wypadku zbycia przedsiębiorstwa}

Teza, że ustawa służy ogólniejszej sukcesji międzypokoleniowej w gospodarce, znajduje dalsze potwierdzenie w nowelizacji ustawy o zarządzie sukce-

${ }^{24}$ Ustawa z dnia 23 kwietnia 1964 roku Kodeks cywilny (tekst jedn. Dz.U. z 2019 r. poz. $1145)$.

25 W postanowieniu SN z dnia 3 grudnia 1966 roku (sygn. III CR 301/66, OSNC 1967/12/220) uznano, że społeczno-gospodarcze przeznaczenie rzeczy (działki) może sprzeciwiać się przejściowo dokonaniu zniesienia współwłasności, a w takim wypadku wniosek o zniesienie współwłasności, jako w danej sytuacji przedwczesny, może ulec oddaleniu z mocy art. 5 k.c. 
syjnym przedsiębiorstwem osoby fizycznej ustawą z dnia 31 lipca 2019 roku $^{26}$. Wprowadzono bowiem wówczas nowy rozdział 7a u.z.s., dotyczący decyzji związanych z przedsiębiorstwem w wypadku zbycia przedsiębiorstwa.

Nabywca przedsiębiorstwa w rozumieniu art. 45b u.z.s. może złożyć do organu administracji publicznej, który wydał decyzję związaną z przedsiębiorstwem, wniosek o przeniesienie na niego tej decyzji w terminie trzech miesięcy od dnia nabycia przedsiębiorstwa, a organ administracji w odpowiedzi na wniosek przenosi taką decyzję, jeśli nabywca przedsiębiorstwa spełnia warunki do uzyskania tej decyzji, określone w odrębnych przepisach (zob. art. 45e ust. 1 u.z.s.). Sama regulacja nie jest spójna, jeśli zważy się, że pojęcie decyzji związanej z przedsiębiorstwem opiera się na związku z wykonywaną przez przedsiębiorcę działalnością gospodarczą (zob. art. 1 pkt 3 u.z.s. w nowym brzmieniu), a uprawnienie do przeniesienia (przejęcia) tego rodzaju decyzji daje się nabywcy przedsiębiorstwa w rozumieniu art. 45b u.z.s., czyli nabywcy przedsiębiorstwa w rozumieniu art. $55^{1}$ k.c., a w tym rozumieniu przedsiębiorstwo jest zorganizowanym zespołem składników, które wspólnie służą realizacji określonego celu gospodarczego ${ }^{27}$ — niemniej jednak w tej regulacji wyraźnie widać zamiar realizacji celów strukturalnych w gospodarce, to znaczy zapewnienia sukcesji międzypokoleniowej w gospodarce, i razem wychodzi się poza krąg rodziny i spadkowych następców prawnych.

\section{Podsumowanie}

W ustawie o zarządzie sukcesyjnym osoby fizycznej można dostrzec regulacje typu publicznoprawnego, które składają się na zasadę kontynuowania działalności gospodarczej z wykorzystaniem przedsiębiorstwa nabytego od innej osoby. Ustawa nie tylko wspiera czy wspomaga majątkową sukcesję międzypokoleniową, lecz służy ogólniejszemu celowi sukcesji międzypokoleniowej w gospodarce, który jest realizowany w warunkach ochrony obrotu gospodarczego oraz interesu publicznego. W ten sposób wspiera się gospodarkę, doprowadzając w niej do pożądanych zmian strukturalnych. Do takich podstawowych elementów przedmiotowej zasady kontynuowania działalności gospodarczej z wykorzystaniem przedsiębiorstwa nabytego od innej osoby można zaliczyć: 1 . specyficzne usytuowanie zarządcy sukcesyjnego, które powoduje, że kieruje się on nie tylko interesami następców prawnych zmarłego, ale względami ogólniejszymi; 2 . mechanizm kontynuacji uprawnień

${ }^{26}$ Ustawa z dnia 31 lipca 2019 roku o zmianie niektórych ustaw w celu ograniczenia obciążeń regulacyjnych (Dz.U. poz. 1495).

27 Zob. np. pojęcie przedsiębiorstwa w rozumieniu art. $55^{1}$ k.c. w wyroku SN z dnia 18 kwietnia 2019 roku (sygn. II CSK 197/18, http://www.sn.pl/orzecznictwo/SitePages/Baza_orzeczen. aspx?ItemSID=40450-57a0abe2-a73c-441d-9691-b79a0c36be5c\&ListName=Orzeczenia3\&Sygnatura-, dostęp: 27.09.2019). 
wynikających z decyzji związanych z przedsiębiorstwem, które uzyskał zmarły przedsiębiorcy, oraz wynikających $\mathrm{z}$ wpisu tego przedsiębiorcy do właściwych rejestrów; 3. reguły działu spadku z uwzględnieniem, że w skład spadku wchodzi przedsiębiorstwo, przy czym w tym zakresie można dostrzec pewną niekonsekwencję w regulacji; 4. mechanizm sukcesji administracyjnoprawnej w wypadku zbycia przedsiębiorstwa przez osobę fizyczną lub wspólników spółki cywilnej, który został wprowadzony nowelizacją z 31 lipca 2019 roku. Wszystkie te regulacje ułatwiają prowadzenie działalności gospodarczej w nawiązaniu do działalności gospodarczego zmarłego przedsiębiorcy czy też poprzednika, opierając się na pozostawionym przez niego lub przekazanym majątku, służąc zarazem interesowi publicznemu. W tym kontekście można też dostrzec zachętę dla następców prawnych zmarłego, aby kontynuowali działalność gospodarczą poprzednika z wykorzystaniem pozostawionego przez niego mienia.

\section{Bibliografia}

Bieluk J., Ustawa o zarządzie sukcesyjnym przedsiębiorstwem osoby fizycznej. Komentarz, Warszawa 2019.

Blicharz R., Zarząd sukcesyjny przedsiębiorstwem w spadku, Warszawa 2019.

Horubski K., Wspieranie gospodarki, [w:] System Prawa Administracyjnego, t. 8a. Publiczne prawo gospodarcze, red. R. Hauser, Z. Niewiadomski, A. Wróbel, Warszawa 2018.

Komunikat Komisji do Parlamentu Europejskiego, Rady, EKES I KR, Plan działania na rzecz przedsiębiorczości do 2020 r. Pobudzanie ducha przedsiębiorczości w Europie (COM/2012/0795 final).

Komunikat Komisji do Rady, Parlamentu Europejskiego, Europejskiego Komitetu Ekonomiczno-Społecznego i Komitetu Regionów, Realizacja wspólnotowego programu lizbońskiego na rzecz wzrostu gospodarczego i zatrudnienia. Przenoszenie własności przedsiębiorstw. Ciągłość poprzez nowy początek (COM/2006/0117 final).

Komunikat Komisji w sprawie przenoszenia własności przedsiębiorstw, Działania na rzecz MŚP (Dz.U. C 204 z 23.07.1994 r.).

Kopaczyńska-Pieczniak K., Status prawny zarządcy sukcesyjnego, „Przegląd Prawa Handlowego” 2018, nr 12.

Minister Przedsiębiorczości i Technologii, Prawo do przedsiębiorczości. Małe firmy, wielkie zmiany, http://prawodoprzedsiebiorczosci.parp.gov.pl/wp-content/uploads/2018/04/PARP-broszura-cala.pdf.

Ministerstwo Przedsiębiorczości i Technologii, Sukcesja firm jednoosobowych. Ustawa o zarządzie sukcesyjnym przedsiębiorstwem osoby fizycznej. Praktyczny poradnik, listopad 2018, http:// firmyrodzinne.pl/wp-content/uploads/2019/01/Sukcesja_firm_jednoosobowych-poradnik-MPiT.pdf.

Morawski L., Zasady wykładni prawa, Toruń 2006.

Uzasadnienie rządowego projektu ustawy o zarządzie sukcesyjnym przedsiębiorstwem osoby fizycznej z dnia 22 lutego 2018 roku (druk nr 2293 Sejmu RP VII kadencji), http://www.sejm. gov.pl/Sejm8.nsf/druk.xsp?nr=2293.

Zalecenie Komisji w sprawie przenoszenia własności małych i średnich przedsiębiorstw (Dz.U. L 385 z 31.12.1994 r.). 


\title{
State support for intergenerational succession in the economy on the basis of the Act on the succession management of a natural person enterprise
}

\author{
Summary
}

The Act on the succession management of a natural person enterprise contains public law regulations that support intergenerational succession in the economy and thus serves the implementation of structural goals. There are several elements of this economy support.

Keywords: succession management, enterprise in decline, structural changes in the economy, transmission of public rights. 